\title{
THE INFLUENCE OF SELF-EFFICACY AND PARENT'S SOCIAL SUPPORTS ON ACADEMIC PROCRASTINATION OF STUDENTS IN YP GKPI JUNIOR HIGH SCHOOL, RAWAMANGUN, INDONESIA
}

\author{
Fretty Elianai, \\ Dinni Jufita Putri, \\ Ahmad Zubaidi \\ Universitas Persada Indonesia YAI, \\ Indonesia
}

\begin{abstract}
:
This present study is intended to investigate the influence of self-efficacy and parent's social supports on academic procrastination of students in YP GKPI junior high school, Rawamangun, Indonesia. Since the population comprising 58 students, a small number of population, this study employed a census method. The instrument involved an academic procrastination scale (34 items), self-efficacy scale (25 items), and parent's social support scale (33 items). The result of multiple regression analysis reveals that the value of $\mathrm{p}<0.05$, meaning that self-efficacy and parent's social support altogether contribute to the academic procrastination behavior significantly. On the other hand, the variable of parent's social support does not significantly contribute to academic procrastination of the students. This is based on the result of coefficient table that the value of $\mathrm{p}>0.05$.
\end{abstract}

Keywords: self-efficacy, parent's social support, academic procrastination behavior

\section{Introduction}

Ferrari (1995) defines procrastination as an action of delaying or postponing works and decision-making. The term academic procrastination is a tendency to postpone or deny responsibilities, decisions, or jobs that should be accomplished (Haycook, McCarthy \& Skay, 1998). Some examples of such negative behaviors are working on assignments and preparing for examinations a night before the due date or the test date despite the fact that the students must prepare themselves earlier.

Numerous studies on academic procrastination behaviors have reported some factors affecting such negative habits; one of the factors is self-efficacy, i.e., the internal factor from the person. Bandura (1997) explains the term self-efficacy as a person's 
confidence in their ability to organize and to carry out a set of activities in achieving individual goals. Students with high self-efficacy work on their assignments immediately. These students are also determined to meet their target. On the other hand, those who have low self-efficacy tend to postpone their academic works (Ellis \& Knaus, 2002). Self-confidence, i.e., believing self-ability is central to the success of students in learning.

Another factor affecting academic procrastination behavior is from the external of the student, such as parent's social support. This type of support refers to the way the parent show their affection to the students. Some of the examples are acceptance, provision of help, as well as showing care and giving rewards to children. Support from the parent contributes to the development of motivation and perseverance of children in an academic setting and thus enhancing the children's achievement. Ferrary and Olivette (1994) opine that poor support from parents can lead to procrastination behavior indirectly.

\section{Research Methodology}

A questionnaire was distributed to the population of this quantitative study. The population involved 58 students in grade VII, VIII, and IX in YP GKPI Junior High School, Rawamangun. The data were collected using a Likert scale model. Furthermore, the instrument consisted of three types, i.e., academic procrastination scale, self-efficacy scale, and parent's social support scale.

The academic procrastination scale is designed based on the indicator by Ferrari and Olivette (1994). The indicator consists of several aspects, such as postponing to work and accomplish assignments, delaying to work assignments, the time gap between plan and actual performance, and doing more enjoyable activities. The scale of self-efficacy used an indicator of measurement by Bandura (1997) comprising of components, namely level of difficulty, generality, and strength. Lastly, the social support variable is measured using a social provisions scale by Robert Weiss (1974). The elements of this scale involve attachment, social integration, the reassurance of worth, reliable alliance, guidance, and opportunity for nurturance.

The data of this present study were scrutinized using a multiple regression analysis method. This method is intended to examine the extent to which the two independent variables, i.e., self-efficacy and parent's social support affect the dependent variable, i.e., academic procrastination. Furthermore, a program called SPSS version 16 for Windows was also used in the data analysis process.

\section{Material and Methods}

Procrastination is among the issues in education that commonly occurred in the learning process. This issue blames internal factor from the student, such as selfefficacy, and external factor, such as parent's social support. The problem of procrastination is illustrated in the following figure. 


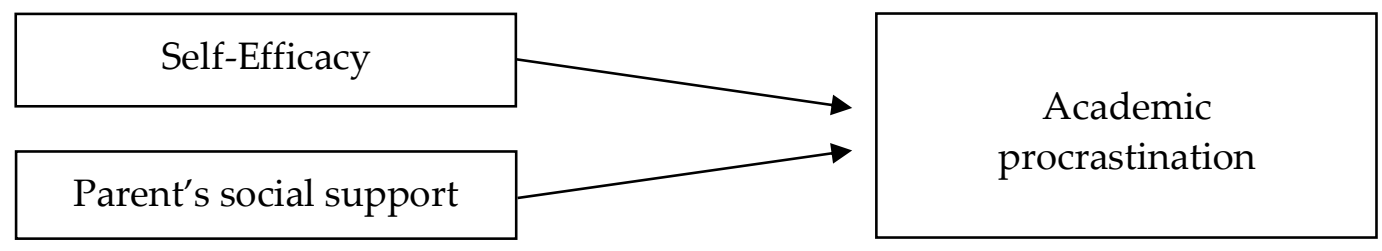

Figure 1: Theoretical Framework

\section{Hypothesis}

Hypothesis 1: Self-efficacy and parent's social supports altogether influence academic procrastination of students in YP GKPI junior high school, Rawamangun.

Hypothesis 2: Self-efficacy influences academic procrastination of students in YP GKPI junior high school, Rawamangun.

Hypothesis 3: Parent's social support influences academic procrastination of students in YP GKPI junior high school, Rawamangun.

\section{Results and Discussion}

The results of data analysis using the SPSS program are as follows:

\begin{tabular}{|c|c|c|c|c|c|c|c|c|c|}
\hline \multicolumn{10}{|c|}{ Model Summary } \\
\hline \multicolumn{2}{|c|}{ Model } & \multicolumn{2}{|c|}{$\mathbf{R}$} & R Square & \multicolumn{2}{|c|}{ Adjusted R Square } & \multicolumn{3}{|c|}{ Std. Error of the Estimate } \\
\hline & 1 & \multicolumn{2}{|c|}{$.919 a$} & .844 & \multicolumn{2}{|r|}{.839} & \multicolumn{3}{|c|}{8.96898} \\
\hline & \multicolumn{9}{|c|}{ Predictors: (Constant), Parent's Social Support, Self-efficacy } \\
\hline \multicolumn{10}{|c|}{ ANOVA $^{b}$} \\
\hline \multicolumn{3}{|c|}{ Model } & & m of Squares & df & Mean Square & $\mathbf{F}$ & \multicolumn{2}{|c|}{ Sig. } \\
\hline 1 & \multicolumn{2}{|c|}{ Regression } & & 23999.810 & 2 & 11999.905 & 149.173 & \multicolumn{2}{|c|}{$.000^{\mathrm{a}}$} \\
\hline & \multicolumn{2}{|c|}{ Residual } & & 4424.345 & 55 & 80.443 & & & \\
\hline & \multicolumn{2}{|l|}{ Total } & & 28424.155 & 57 & & & & \\
\hline & \multicolumn{6}{|c|}{ Predictors: (Constant), Parent's Social Support, Self-efficacy } & & & \\
\hline \multicolumn{10}{|c|}{ Coefficientsa } \\
\hline \multirow{2}{*}{\multicolumn{5}{|c|}{ Model }} & \multicolumn{2}{|c|}{$\begin{array}{l}\text { Unstandardized } \\
\text { Coefficients }\end{array}$} & \multirow{2}{*}{$\begin{array}{c}\text { Standardized } \\
\text { Coefficients }\end{array}$} & \multirow[b]{2}{*}{$\mathbf{t}$} & \multirow[b]{2}{*}{ Sig. } \\
\hline & & & & & B & Std. Error & & & \\
\hline \multirow{3}{*}{\multicolumn{2}{|c|}{$\begin{array}{l}(\mathrm{C} \\
\mathrm{S} \\
\mathrm{P}\end{array}$}} & \multicolumn{3}{|c|}{ (Constant) } & 186.425 & 4.281 & & 43.552 & .000 \\
\hline & & \multicolumn{3}{|c|}{ Self-efficacy } & -1.014 & .114 & -.942 & -8.899 & .000 \\
\hline & & \multicolumn{3}{|c|}{ Parent's Social Support } & .018 & .070 & .027 & .254 & .800 \\
\hline \multicolumn{6}{|c|}{ a. Dependent Variable: Procrastination } & & & & \\
\hline
\end{tabular}

The result of multiple regression analysis reveals that the value of $R=0.919$ and $R$ square $=0.844$, where $F=149.173$ with the significance level at $0.000(p<0.05)$. This 
result suggests that the self-efficacy and parent's social support significantly contribute to the academic procrastination behavior with a percentage of $84.4 \%$. The remaining $15.6 \%$ refers to other variables excluded from this present study.

This condition also applies to the variable of self-efficacy. The result of coefficient table analysis reveals that the value of beta $(\beta)=-0.942$ with the significance level at $0.000(\mathrm{p}<0.05)$. In other words, the variable of self-efficacy significantly contributes to academic procrastination behavior.

On the other hand, the result of coefficient table analysis for the variable of parent's social support reveals that the value of beta $(\beta)=0.027$ with the significance level at $0.800(\mathrm{p}>0.05)$. This finding indicates that the variable of parent's social support does not contribute to the academic procrastination behavior significantly.

\section{Discussion}

This research finds that the self-efficacy and parent's social support significantly contribute to the academic procrastination behavior, where $F=149.173$ with the significance level at $0.000(\mathrm{p}<0.05)$ with a percentage of $84.4 \%$. Such a finding resonates to the theory by Ellis \& Knaus (2002) that students with high self-efficacy work on their assignments immediately and are determined to meet their target. On the other hand, those who have low self-efficacy tend to postpone their academic works. Selfconfidence, i.e., believing self-ability is central to the success of students in learning. Furthermore, the finding of this present study is in line with the result seen in Lee, Bong and Kim (2004) that self-efficacy has a significant influence on academic procrastination. On the other hand, this study finds out that the variable of parent's social support gets the value of beta $(\beta)=0.027$ with the significance level at $0.800(p>0.05)$. This finding reveals that the variable of parent's social support does not contribute to the academic procrastination behavior significantly. Ferrari (1995) asserts that external factors of an individual, e.g., parenting and environmental situation, can affect procrastination behaviors in an academic setting.

The result seen in this present study is supported by Bandura's theory (1986) that a person requires high self-confidence to carry out their works.

\section{Recommendations}

Drawing on the result of this study and data analysis, the recommendations are as follows:

\section{A. Theoretical Recommendations}

In addition to the opinion by Ferrari (1995) regarding the influence of internal factors on students' procrastination, the psychological condition of learners has a significant contribution to the behavior of procrastination in an academic setting. Environment condition and parenting, the external factors, also affect such negative behavior. Therefore, future research is urged to examine the effect of physical condition, parenting, and environmental condition. In-depth investigations with wider scope 
regarding the academic procrastination are also necessary; the studies should be conducted in all level of education, not only in junior high level.

\section{B. Practical Recommendations}

- This present study shows that a high level of students' self-efficacy reduces the number of procrastination issues among students. Such a finding suggests that students should be determined and should believe themselves to attain a satisfactory goal. This attitude can be actualized by studying diligently.

- Schools, especially teachers, are expected to provide positive supports actively to their students in learning. This is intended to motivate the students to earn the achievement in school. Furthermore, the schools should monitor the psychology of the students. Teachers are also required to be more creative in modeling positive behaviors to improve students' self-efficacy by which it overcomes the students' procrastination.

\section{Conclusion}

- Self-efficacy and parent's social supports altogether influence academic procrastination of the students in YP GKPI junior high school, Rawamangun.

- This study also finds that self-efficacy affects academic procrastination of the students in the research site. In other words, the higher the self-efficacy of the students, the lower the issue of academic procrastination.

On the other hand, parent's social supports do not influence academic procrastination of the students in the research site significantly. This finding suggests that there are other contributing factors of procrastination behavior.

\section{About the Author(s)}

All the activities in this article have been done by Fretty Eliana.

\section{References}

Bandura, A. (1997). Self-efficacy, the exercise of control. New York: W.H. Freeman and Company.

Beck, B. L., Koons, S. R., \& Milgram, D. L. (2000). Correlates and consequences of behavioral procrastination: the effects of academic procrastination, selfconsciousness, self-esteem, and self-handicapping. Journal of Social Behavior and Personality, 15, 3-13.

Burka, J. B., \& Yuen, L. M (1983). Procrastination: why you do it, what to do about it. New York, Perseus Books.

Cervone, D., and Lawrence, A. P. (2012). Kepribadian: teori dan penelitian [Personality: theory and research]. Salemba Humanika, Jakarta, Indonesia.

Cohen, Sheldon. \& Syme, S. Leonard (1985). Social support and health. Academic Press, Florida, USA. 
Cutrona, E. C., \& Russell, D. W. (1987). The provisions of social relationship and adaptation to stress. Journal Advances in Personal Relationship, Volume 1, 37 67.

Ellis, A., \& Knaus, W. J. (2002). Overcoming procrastination. New York, US: New American Library.

Ferrari, J. R., Jhonson, J. L., \& McCown, W. G. (1995). Procrastination and task avoidance: theory, research and treatment. New York: Plenum Press.

Ferrari, J. R., \& Olivette, M. J. (1994). Parental authority and the development of female dysfunctional procrastination. Journal of Research in Personality, 28, 87-91.

Haycook, L. A. McCarthy, P., \& Skay, C. L. (1998). Procrastination in college student: the role of self-efficacy and anxiety. Journal of Counseling and Development, 76: 317324.

Klassen, R. M., Krawchuck, L. L., \& Rajani, S. (2007). Academic procrastination of undergraduates: low self-efficacy to self-regulate predicts higher levels of procrastination. Journal of Contemporary Educational Psychology. 33(4):915-931.

Mih, V. (2013). Role of parental support for learning autonomous/control motivation and forms of self-regulation on academic attainment in high school students: a path analysis, cognition, brain, and behavior. An Interdisciplinary Journal, 17, 3539.

Muti ah, N. (2000). Peran belajar berdasarkan regulasi diri, dukungan sosial, keluarga dan efikasieiri terhadap prokrastinasi akademik. Jurnal Psikologi [The role of learning based on self-regulation, social support, family and self-efficacy towards academic procrastination. Journal of Psychology]. Universitas Ahmad Dahlan, Yogyakarta, Indonesia.

Ormrod, J. E. (2008). Psikologi Pendidikan Jilid 2 [Educational Psychology Vol.2]. Penerbit Erlangga, Jakarta, Indonesia.

Ozer, B. U., Demir, A., \& Ferrari, J. R. (2009). Exploring academic procrastination among Turkish student: possible gender differences in prevalence and reasons. The Journal of Social Psychology. 149(2):241-257.

Ruholt, R., Gore, S. J., and Dukes, K. (2015). Is parental support or parental involvement more important for adolescents? Undergraduate Journal of Psychology, Volume 28, No.1. Eastern Kentucky University.

Santrock, John W. (2003). Perkembangan Remaja Edisi Keenam [Development of Adolescent, Sixth Edition]. Erlangga, Jakarta.

Seo, E. H. (2008). Self-efficacy as a mediator in the relationship between self-oriented perfectionism and academic procrastination. Journal of Social Behavior and Personality. 36(6):753-764.

Shaw, B. A., Krause, N., Chatters, L. M., Connell, C. M., \& Ingersoll-Dayton, B. (2004). Emotional Support from parents in early life, aging, and health. Journal of Psychology and Aging. 19(1):4-12.

Sugiyono (2008). Metode Penelitian Kuantitatif Kualitatifdan RED [Quantitative, Qualitative, and R\&D Research Methodology]. Alfabeta, Bandung, Indonesia. 
Yuana Zahra \& Neti Hemawati (2015). Prokrastinasi akademik menghambat peningkatan prestasi akademik remaja di wilayah perdesaan. Jurnal Ilmu Keluarga dan Konsumen [Academic procrastination inhibits the increase of academic achievement of the adolescent in rural areas. Journal of Family and Consumer Sciences]. Institut Pertanian Bogor, Bogor, Indonesia.

Zakeri, H., Esfahani, B. N., N. E., \& Razmjoee, M. (2013). Parenting styles and academic procrastination. Journal of Social and Behavioral Science. Iran: University of Shiraz. makes clear that the materials are being reused under permission of a Creative Commons License. Views, opinions and conclusions expressed in this research article are views, opinions and conclusions of the author(s). Open Access Publishing Group and European Journal of Education Studies shall not be responsible or answerable for any loss, damage or liability caused in relation to/arising out of conflicts of interest, copyright violations and inappropriate or inaccurate use of any kind content related or integrated into the research work. All the published works are meeting the Open Access Publishing requirements and can be freely accessed, shared, modified, distributed and used in educational, commercial and non-commercial purposes under a Creative Commons Attribution 4.0 International License (CC BY 4.0). 